\title{
Coexistence of sulfate reduction and methane production in an organic-rich sediment
}

\author{
Marianne Holmer*, Erik Kristensen \\ Institute of Biology, Odense University, Campusvej 55, DK-5230 Odense M, Denmark
}

\begin{abstract}
Anaerobic mineralization processes were studied over a period of $40 \mathrm{~d}$ in an organic-rich sediment amended with labile organic matter (fish food pellets). Although measured sulfate reduction rates (SRR) were high ( $u p$ to $-2400 \mathrm{nmol} \mathrm{cm}^{-3} \mathrm{~d}^{-1}$ ), a coexistence between sulfate-reducing bacteria (SRB) and methane-producing bacteria (MPB) was evident. Methane production rates (MPR) of the same order of magnitude as SRR (up to $-1300 \mathrm{nmol} \mathrm{cm} \mathrm{cm}^{-3} \mathrm{~d}^{-1}$ ) occurred even when sulfate was present in high concentrations ( 5 to $60 \mathrm{mM}$ ). Acetate was an important substrate for the SRB initially, but its role diminished after $180 \mathrm{~h}$ of incubation, indicating that SRB used other substrates than acetate. There was only minor competition for acetate between SRB and MPB, as indicated by the lack of effect on MPR by inhibition of SRB with molybdate. This provides a possible explanation for the coexistence between $\mathrm{SRB}$ and MPB; in this organic-rich sediment the concentration of competitive substrates either exceeds the competition level or substrates are used noncompetitively.
\end{abstract}

KEY WORDS: Fish farm sediment - Sulfate reduction - Methanogenesis - Acetate oxidation

\section{INTRODUCTION}

The anaerobic mineralization of organic matter in marine sediments primarily occurs via sulfate reduction, and methanogenesis usually accounts for less than $5 \%$ (Kuivila et al. 1990). Methanogenesis is only important in sediments with high sedimentation rates and sulfate depletion in the upper organic-rich layers (Martens \& Klump 1984, Crill \& Martens 1986). Several mechanisms have been proposed to explain the spatial separation of sulfate reduction and methanogenesis in marine sediments. Competition for electron donors between sulfate-reducing bacteria (SRB) and methane-producing bacteria (MPB) has received considerable attention (Oremland \& Taylor 1978, Sansone \& Martens 1981, 1982, Crill \& Martens 1986, Kuivila et al. 1990). SRB apparently have a higher affinity (lower $K_{\mathrm{m}}$ ) for the major precursors hydrogen and acetate than MPB (see Table 1). The $K_{\mathrm{m}}$ value for hydrogen is about $1 \mu \mathrm{M}$ for SRB and $6 \mu \mathrm{M}$ for

\footnotetext{
-Present address: Department of Life Sciences and Chemistry, Roskilde University, PO Box 260, DK-4000 Roskilde, Denmark
}

MPB (Kristjansson et al. 1982), and for acetate the $K_{\mathrm{m}}$ values for SRB and MPB are $200 \mu \mathrm{M}$ and $3 \mathrm{mM}$, respectively (Schönheit et al. 1982). This enables SRB to maintain the pool of these substrates at concentrations too low for MPB, when sulfate is not limiting. Coexistence between SRB and MPB has been determined in organic-rich sediments, but with methane production rates accounting for $<10 \%$ of the sulfate reduction rates (Crill \& Martens 1986).

Sediments underlying marine fish farms are generally exposed to high organic loading of labile waste products, and benthic metabolism is usually stimulated significantly (Hall et al. 1990, Holmer \& Kristensen 1992). Due to the lack of bioturbation in these sediments, elevated organic levels are restricted to the surface layers, where sulfate reduction activity may attain exceptionally high rates. Accumulation of substrates, e.g. acetate, for the SRB and MPB has been observed despite the high mineralization rates. The presence of methane bubbles in these sulfate-containing upper sediment layers may indicate a coexistence of SRB and MPB (Holmer \& Kristensen unpubl.).

The purpose of the present work was to examine the anaerobic mineralization processes in an organic-rich 
sediment receiving a high input of labile organic matter with special emphasis on sulfate reduction and methane production. The uptake kinetics of, and competition for, available electron donors between SRB and MPB are evaluated by the use of specific inhibitors.

\section{MATERIALS AND METHODS}

Sample collection and preparation procedures. Surface sediment ( 0 to $5 \mathrm{~cm}$ ) was collected under a marine salmon farm (Kolding Fjord, Denmark) with a VanVeen grab before initiation of fish farming in March 1993. Water temperature was $5^{\circ} \mathrm{C}$ and the salinity $15 \%$. After return to the laboratory, the sediment was sieved through $1 \mathrm{~mm}$ mesh to remove larger particles (no macrofauna was present). Subsequently, the sulfate concentration was raised to $\sim 50 \mathrm{mM}$ by adding $\mathrm{Na}_{2} \mathrm{SO}_{4}$. After acclimation for $7 \mathrm{~d}$ at $5{ }^{\circ} \mathrm{C}$ under anaerobic conditions the sediment was split into 2 portions. One was maintained as a control (particulate organic carbon (POC) content was $5819 \mu$ moi $\mathrm{C}^{-1}$ dry wt and the particulate organic nitrogen (PON) content was $\left.\left.393 \mu \mathrm{mol} \mathrm{N} \mathrm{g}^{-1} \mathrm{dry} w \mathrm{t}\right)\right\}$. Homogenised food pellets (ECOLINE 19, Dansk Ørredfoder) $\left(680 \mu \mathrm{mol} \mathrm{C} \mathrm{g}^{-1} \mathrm{dry}\right.$ wt sediment and $82 \mu \mathrm{mol} \mathrm{N} \mathrm{g}^{-1}$ dry wt) were added to the other portion, increasing the POC and PON by $12 \%$ and $21 \%$ respectively. Subsequently, both sediment types were transferred into three 1 l gas-tight polyester/polyethylene bags (Ril-O-Ten 80/160) (Kruse 1993). One bag from each treatment ( \pm food pellets) received $\mathrm{Na}_{2} \mathrm{MoO}_{4}$ to a final concentration of $\sim 100 \mathrm{mM}$ to inhibit sulfate reduction (Oremland \& Capone 1988). All bags were incubated at $5^{\circ} \mathrm{C}$ for approximately 1 mo, and subsampled once or twice a week.

Pore water solutes. Pore water was obtained by squeezing through combusted $\left(300^{\circ} \mathrm{C}\right)$ Whatman $\mathrm{GF} / \mathrm{C}$ filters (Reeburgh 1968). After discarding the first $1 \mathrm{ml}, 5$ to $10 \mathrm{ml}$ was sampled for: sulfate $\left(\mathrm{SO}_{4}{ }^{2-}\right)$, total $\mathrm{CO}_{2}\left(\mathrm{TCO}_{2}\right)$, and short-chain fatty acids (SCFA) $\left(\mathrm{C}_{1}-\mathrm{C}_{4}\right)$ analysis. Samples for $\mathrm{SO}_{4}{ }^{2-}$ were preserved in $\mathrm{HCl}(\mathrm{pH} 2)$ and stored at $5^{\circ} \mathrm{C}$ until analysis by HPLC anion chromatography with potassium phthalate as eluent and UV detection (precision better than $3 \%$ ). $\mathrm{TCO}_{2}$ was determined within $24 \mathrm{~h}$ by flow injection analysis according to Hall \& Aller (1992) with $30 \mathrm{mM}$ $\mathrm{HCl}$ as carrier and $10 \mathrm{mM} \mathrm{NaOH}$ as receiver with a precision better than $4 \%$. Interfering sulfides were precipitated with $\mathrm{ZnCl}_{2}$. Samples for SCFA analysis were stored frozen until analysis. SCFA were measured by the HPLC method of Bøtte \& Jørgensen (1992) modified for seawater analysis. The column was an IC-PAK Ion-Exclusion (Waters Assoc.) with a GuardPak module and $1.00 \mathrm{mM} \mathrm{H}_{2} \mathrm{SO}_{4}$ as eluent followed by an Anion MicroMembrane Suppressor (AMMS-ICE, Dionex Corp.) with $5.00 \mathrm{mM}$ tetrabutyl ammoniumhydroxide $(\mathrm{TBaOH})$ as regenerant. The precision was better than $5 \%$. pH was measured on intact sediment by inserting a pH glass-electrode (Radiometer) directly into the sediment and allowing the reading to stabilize $(<3 \mathrm{~min})$.

Sediment characteristics. Density was obtained on subsamples from wet weights of known sediment volume. Water content was determined after drying at $105^{\circ} \mathrm{C}$ for $6 \mathrm{~h}$. POC and PON were determined with a Carlo Erba Elemental Analyzer EA 1100A after the method of Kristensen \& Andersen (1987).

Acetate oxidation. Acetate oxidation was measured on subsamples from the sediment bags. Samples were taken by cut-off plastic syringes $\left(5 \mathrm{~cm}^{3}\right)$, and sealed with butyl stoppers. A volume of 4 to $20 \mu$ l of uniformly labelled ${ }^{14} \mathrm{C}$-acetate $\left(50\right.$ to $60 \mathrm{mCi} \mathrm{mmol}^{-1}$; Amersham International, England) was injected through the stoppers, increasing the acetate concentration by 0.5 to $18 \mu \mathrm{M}$. The specific activity ranged between 0.05 and $1 \mu \mathrm{Ci} \mathrm{ml} l^{-1}$ adjusted to the acetate pool. The syringes were incubated under $\mathrm{N}_{2}$ in duplicate for time series of 10 to $480 \mathrm{~min}$ (amended sediment) and 10 to $60 \mathrm{~min}$ (control sediment) before termination by transferring the sediment into $5 \mathrm{ml} 625 \mathrm{mM} \mathrm{NaOH}$. Acetate oxidation was also determined when sulfate reduction was inhibited by injecting molybdate to a concentration of $\sim 100 \mathrm{mM} 10$ to $15 \mathrm{~min}$ before the acetate tracer injection. Supernatants were obtained immediately after $\mathrm{NaOH}$ fixation by centrifugation $(3000 \mathrm{rpm}, 2500 \times \mathrm{g}$, $5 \mathrm{~min})$. Separation of tracer into ${ }^{14} \mathrm{C}$-acetate and ${ }^{14} \mathrm{C}$ $\mathrm{CO}_{2}$ was done by microdiffusion according to the method of Lund \& Blackburn (1989) on triplicate supernatant subsamples. ${ }^{14} \mathrm{CO}_{2}$ was liberated by acidification with $3 \mathrm{M} \mathrm{HCl}$ for $6 \mathrm{~h}$. Tests showed no release of ${ }^{14} \mathrm{C}$-acetate during this process. Radioactivity was determined on a Packard TRI-CARB Liquid Scintillation Counter. Acetate oxidation was estimated by least squares linear regression analysis of the time-dependent ${ }^{14} \mathrm{CO}_{2}$ evolution (minimum 3 time points, $\mathrm{R}^{2}>$ 0.85 ), and oxidation rates were determined using the corresponding acetate concentration. Measurements of label recovery indicated that adsorption onto particles and/or incorporation into bacteria was minimal (less than $5 \%$ ) during the incubation

Sulfate reduction rates. Sulfate reduction rates (SRR) were determined on 4 parallel subsamples at weekly intervals. Samples were taken by syringes as described above. Volumes of $2 \mu \mathrm{l}^{35} \mathrm{~S}_{-} \mathrm{SO}_{4}{ }^{2-}(70 \mathrm{kBq})$ were injected, and syringes were incubated for $4 \mathrm{~h}$ under $\mathrm{N}_{2}$. Incubation was stopped by fixation in $5 \mathrm{ml}$ $1 \mathrm{M} \mathrm{ZnAc}$, and held for 2 to $5 \mathrm{~h}$ at room temperature to ensure complete precipitation before freezing. Background activity was determined once, with injec- 
tion of tracer after fixation. The sediment was distilled according to the 1-step method of Fossing \& Jørgensen (1989) without prior washing. The distillation was run for $30 \mathrm{~min}$ of boiling, and liberated sulfides were trapped in $250 \mathrm{mM}$ buffered $\mathrm{ZnAc}$. Radioactivity was counted on subsamples from supernatant $\left({ }^{35} \mathrm{~S}\right.$ $\left.\mathrm{SO}_{4}{ }^{2-}\right)$ and traps $\left({ }^{35} \mathrm{~S}-\sum \mathrm{H}_{2} \mathrm{~S}\right)$ with Ultima Gold scintillation cocktail on a Packard TRI-CARB Liquid Scintillation Counter.

Methane production. Methane production rates (MPR) were measured weekly from duplicate incubations of subsampled sediment. About $10 \mathrm{~g}$ sediment was transferred to $25 \mathrm{ml}$ serum bottles (preflushed with $\mathrm{N}_{2}$ for $2 \mathrm{~min}$ ) leaving a headspace of $\sim 15 \mathrm{ml}$, and capped with butyl stoppers. Another set of bottles was treated similarly, except for injection of molybdate to a concentration of $\sim 100 \mathrm{mM}$ before capping to inhibit sulfate reduction. All bottles were incubated on a shaking table for up to $8 \mathrm{~h}$ to obtain the time-dependent increase in methane concentration. During the incubation 4 instant measurements of headspace $\mathrm{CH}_{4}$ concentration were done on a Hewlett-Packard gas chromatograph $5380 \mathrm{~A}$ with a Poropak-Q column $(80 / 100,1 \mathrm{~m})$. The temperature of the flame ionization detector was $230^{\circ} \mathrm{C}$ and oven temperature $130^{\circ} \mathrm{C} . \mathrm{N}_{2}$ was used as carrier gas with a flow of $20 \mathrm{ml} \mathrm{min}^{-1}$. Standards were prepared from $>99.5 \%$ pure $\mathrm{CH}_{4}$ gas, and the precision on measurements was better than $2 \%$. Only time points where the accumulation of methane in the headspace was linear were used for the calculation of MPR by least squares linear regression $\left(\mathrm{R}^{2}>0.90\right)$.

\section{RESULTS}

\section{Amended sediment}

There was a rapid mineralization of the added food pellets in the amended sediment. The accumulation of $\mathrm{TCO}_{2}$ was linear with time and attained a rate of 1223 $\pm 40 \mathrm{nmol} \mathrm{cm}^{-3} \mathrm{~d}^{-1}$ (Fig. 1). Sulfate reduction was evident as a linear decrease in sulfate concentrations, providing a rate of $1488 \pm 21 \mathrm{nmol} \mathrm{cm} \mathrm{cm}^{-3} \mathrm{~d}^{-1}$ (Fig. 2). The tracer-determined SRR increased with time reaching a maximum of $2477 \mathrm{nmol} \mathrm{cm}^{-3} \mathrm{~d}^{-1}$ after $\sim 500 \mathrm{~h}$, followed by gradually decreasing rates to $\sim 250 \mathrm{nmol}$ $\mathrm{cm}^{-3} \mathrm{~d}^{-1}$ after $-1000 \mathrm{~h}$ of incubation (Fig. 3).

Acetate, which was the only SCFA measured above the detection limit, was low initially $(-500 \mu \mathrm{M})$, but increased rapidly to $\sim 5 \mathrm{mM}$ after $200 \mathrm{~h}$ incubation followed by a gradual decrease to $\sim 100 \mu \mathrm{M}$ towards the end $(800 \mathrm{~h}$ ) (Fig. 4$)$. The acetate oxidation rates (400 to $840 \mathrm{nmol} \mathrm{cm}^{-3} \mathrm{~d}^{-1}$ ) corresponded to SRR during the initial time period $<180 \mathrm{~h}$, but decreased subsequently

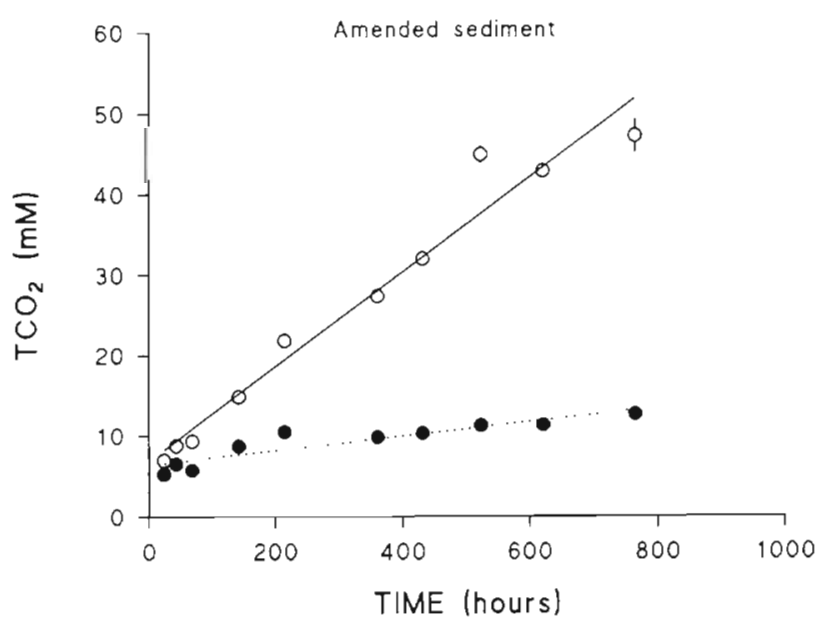

Fig. 1. Concentration of $\mathrm{TCO}_{2}$ as a function of incubation time with ( ) and without (O) molybdate inhibition in the amended sediment. Lines are fitted by least squares linear regression analysis. Each symbol represents the mean ( \pm SE) of 2 bags for the noninhibited sediment, or 1 bag for the inhibited sediment

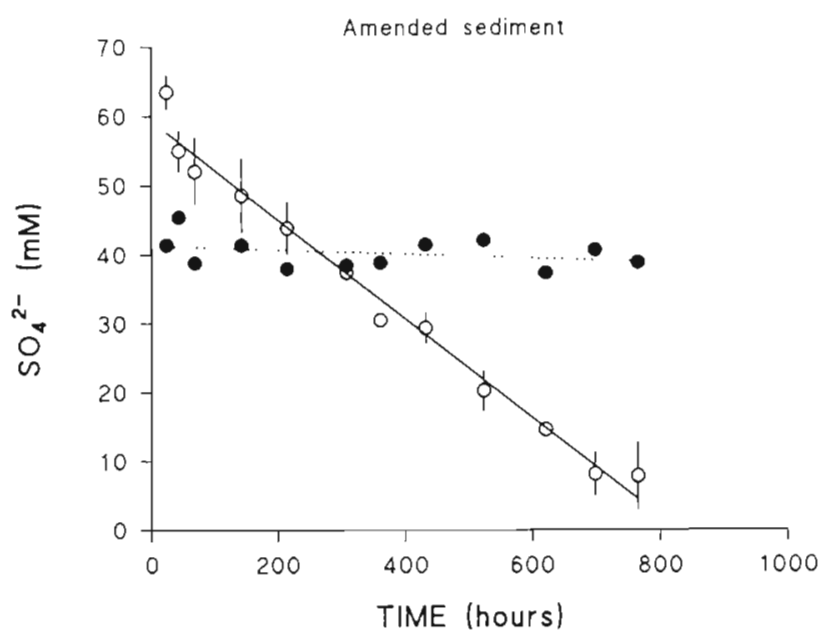

Fig. 2. Concentration of $\mathrm{SO}_{4}{ }^{2-}$ as a function of incubation time with ( ) and without (O) molybdate inhibition in the amended sediment. Lines are fitted by least squares linear regression analysis. Each symbol represents the mean ( $\pm \mathrm{SE}$ ) of 2 bags

for the noninhibited, or 1 bag for the inhibited sediment

reaching $160 \mathrm{nmol} \mathrm{cm}^{-3} \mathrm{~d}^{-1}$ at the end of the experiment (Fig. 3). Rate constants ( $k$ ) changed significantly during the experiment from low values 10.004 to 0.01 $\mathrm{h}^{-1}$ ) at high acetate concentrations, followed by a gradual increase with the decreasing pool (up to $0.1 \mathrm{~h}^{-1}$ ). Inhibition of SRB by molybdate injection in the syringes almost stopped the acetate oxidation, as only

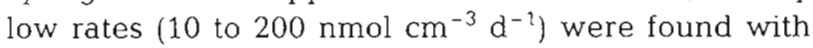
maximum at $\sim 400 \mathrm{~h}$ (Fig. 3 ). 
Methane was produced during the entire incubation period (Fig. 5). The rates increased rapidly up to $\sim 950$ nmol $\mathrm{cm}^{-3} \mathrm{~d}^{-1}$ after $180 \mathrm{~h}$ with a peak value of $\sim 1370$ $\mathrm{nmol} \mathrm{cm} \mathrm{cm}^{-3} \mathrm{~d}^{-1}$ after $420 \mathrm{~h}$ followed by decreasing rates towards the end $\left(\sim 700 \mathrm{nmol} \mathrm{cm}^{-3} \mathrm{~d}^{-1}\right)$. Inhibition of sulfate reduction with molybdate only affected the methane production rates significantly between 300 and $400 \mathrm{~h}$ (increased up to $1800 \mathrm{nmol} \mathrm{cm} \mathrm{cm}^{-3} \mathrm{~d}^{-1}$ ).

$\mathrm{pH}$ was relatively invariable with values between 7.0 and 7.5 throughout the incubation period in amended as well as in control sediments.

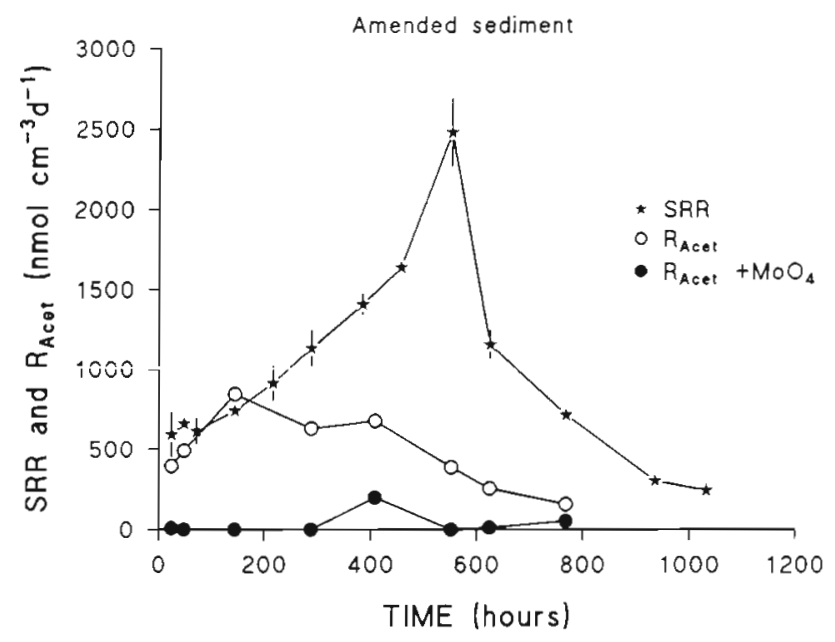

Fig. 3. Radiotracer-determined sulfate reduction rates (SRR) ( ) and rates of acetate oxidation with (-) and without (O) molybdate inhibition as a function of incubation time in the amended sediment. Error bars for SRR indicate \pm SE of 4 determinations

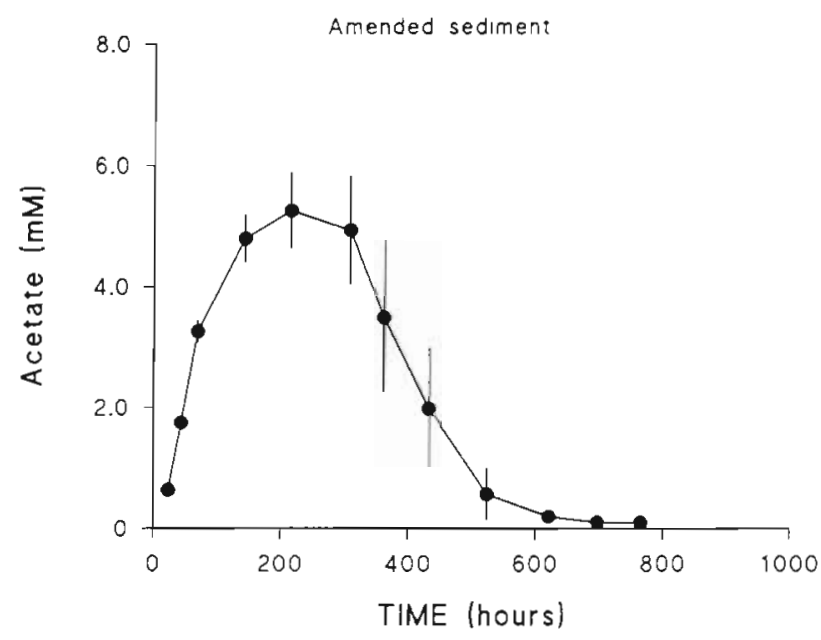

Fig. 4. Acetate concentration as a function of incubation time in the amended sediment. Results are the mean $( \pm \mathrm{SE})$ of the 2 bags

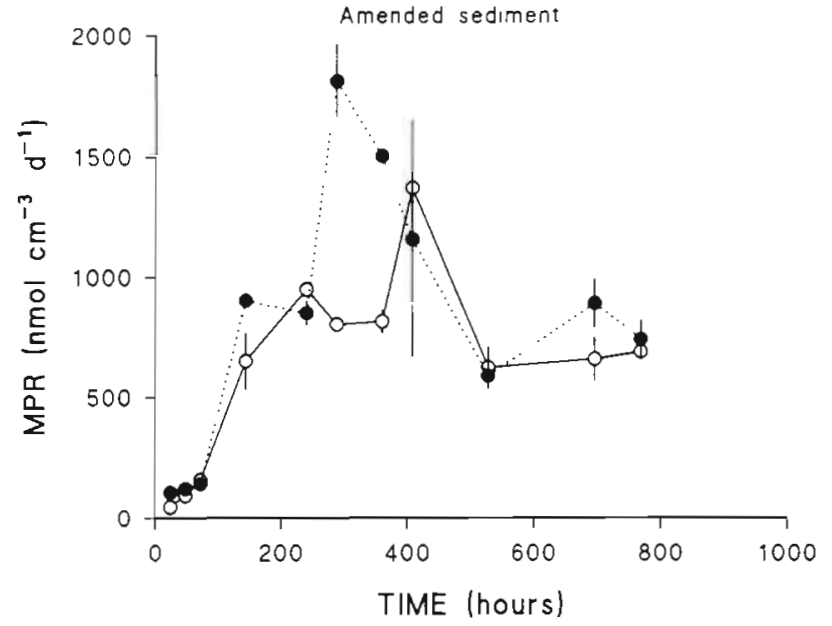

Fig. 5. Methane production rates with $(\bullet)$ and without $(0)$ molybdate inhibition as a function of incubation time in the amended sediment. Results are the mean $( \pm \mathrm{SE})$ of 2 incubations

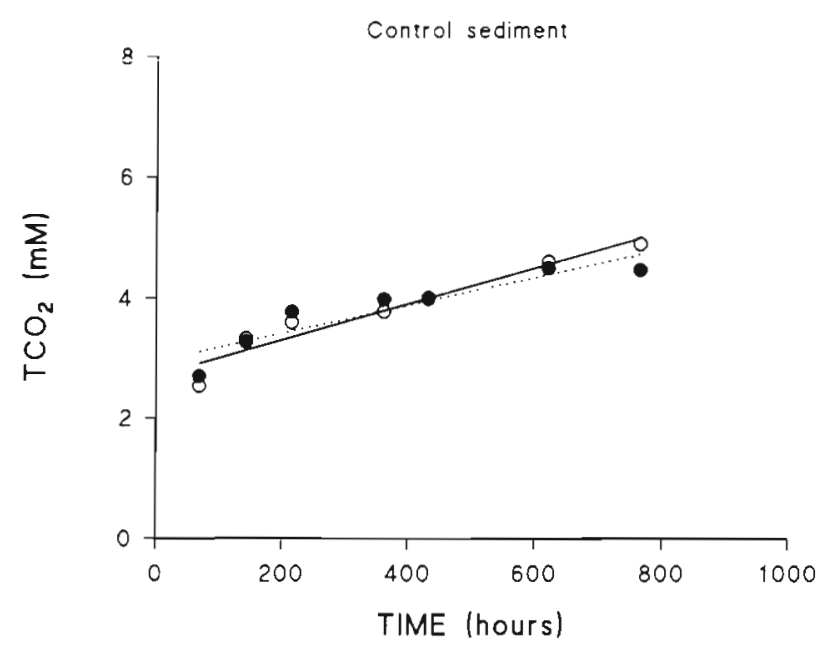

Fig. 6. Concentration of $\mathrm{TCO}_{2}$ as a function of incubation time with ( ) and without (0) molybdate inhibition in the control sediment. Lines are fitted by least squares linear regressionanalysis. Each symbol represents the mean $( \pm S E)$ of 2 bags for the noninhibited sediment, or $1 \mathrm{bag}$ for the inhibited sediment

\section{Control sediment}

The $\mathrm{TCO}_{2}$ production in the control sediment was only about $5 \%\left(62.1 \pm 1.7 \mathrm{nmol} \mathrm{cm} \mathrm{cm}^{-3} \mathrm{~d}^{-1}\right)$ of the rate obtained in the amended sediment (Fig. 6). The corresponding decrease in sulfate concentration was undetectable (data not shown), but the tracer-determined rates varied between 42 and $55 \mathrm{nmol} \mathrm{cm} \mathrm{cm}^{-3} \mathrm{~d}^{-1}$ throughout the incubation period (data not shown).

Acetate concentration also remained low in controls $(<10 \mu \mathrm{M})$ with acetate oxidation rates an order of 
magnitude lower than in the amended sediment (41 to $65 \mathrm{nmol} \mathrm{cm}^{-3} \mathrm{~d}^{-1}$ ), but similar to the sulfate reduction rates. The rate constants $(k)$ ranged between 0.24 and $0.36 \mathrm{~h}^{-1}$ throughout the experiment. There was no measurable oxidation of acetate when sulfate reduction was inhibited with molybdate, and methane production was below detection limit for up to $8 \mathrm{~h}$ of incubation, also with molybdate inhibition (data not shown)

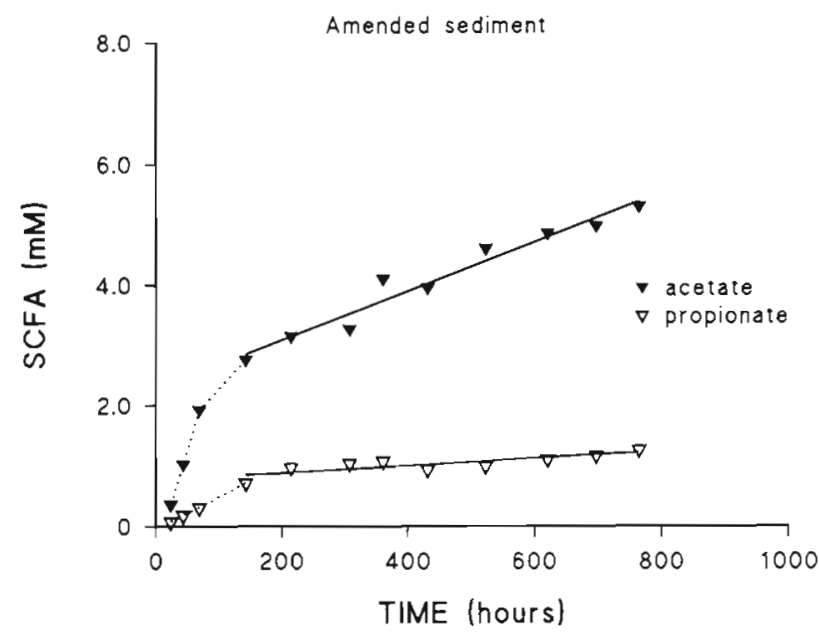

Fig. 7. Concentration of acetate $(\nabla)$ and propionate $(\nabla)$ as a function of incubation time in amended molybdate-inhibited sediment. Solid lines are fitted by least squares linear regression

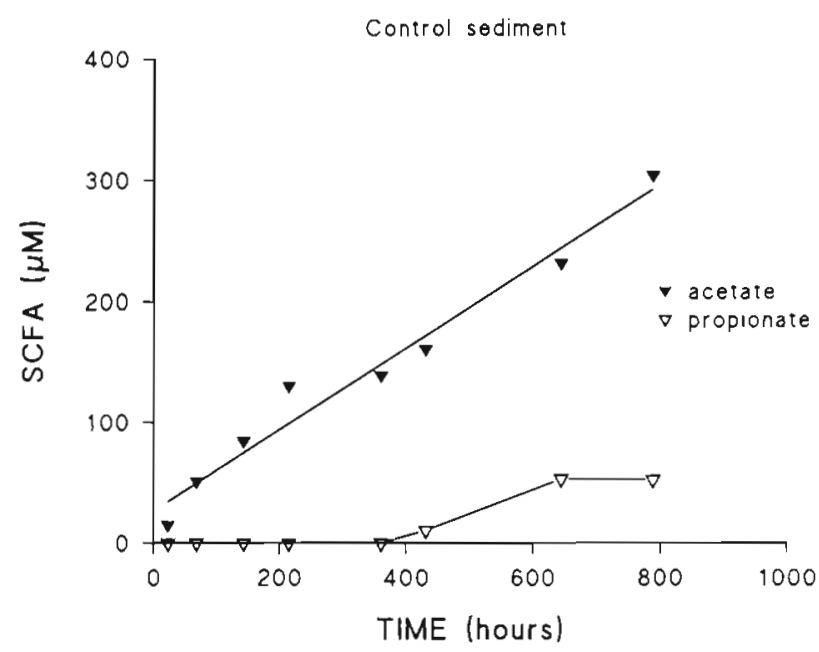

Fig. 8. Concentration of acetate $(\boldsymbol{\nabla})$ and propionate $(\boldsymbol{\nabla})$ as a function of incubation time in molybdate-inhibited control sediment. The line for acetate concentration is fitted by least squares linear regression

\section{Amended sediment with long-term molybdate inhibition}

There was no change in sulfate concentration in the long-term molybdate-treated sediment (Fig. 2) indicating that the sulfate reduction was completely inhibited. There was, however, a significant linear increase in the $\mathrm{TCO}_{2}$ concentration (Fig. 1), at a rate of $185 \mathrm{nmol}$ $\mathrm{cm}^{-3} \mathrm{~d}^{-1}$.

Acetate and propionate concentrations increased rapidly initially (until $\sim 48 \mathrm{~h}$ ) followed by constant accumulation with rates of 84.7 and $12.4 \mathrm{nmol} \mathrm{cm}^{-3} \mathrm{~d}^{-1}$, respectively (Fig. 7). Concentrations of 5 and $1 \mathrm{mM}$ for acetate and propionate, respectively, were reached after $800 \mathrm{~h}$ of incubation. No measurements of acetate oxidation and methane production were done on this sediment.

\section{Control sediment with molybdate inhibition}

The sulfate reduction was completely inhibited, as in the amended sediment, but a linear increase in $\mathrm{TCO}_{2}$ concentration was evident ( $46 \mathrm{nmol} \mathrm{cm} \mathrm{nd}^{-3} \mathrm{~d}^{-1}$ ) (Fig. 6). Acetate also increased linearly at a rate of $7.0 \mathrm{nmol} \mathrm{cm}^{-3}$ $\mathrm{d}^{-1}\left(\mathrm{R}^{2}=0.97\right)$ reaching $\sim 300 \mu \mathrm{M}$ at the end (Fig. 8). Propionate was only detected after $400 \mathrm{~h}$ of incubation, reaching a concentration of $<55 \mu \mathrm{M}$ at the end.

\section{DISCUSSION}

\section{Amended sediment}

A significant stimulation of anaerobic mineralization due to addition of food pellets was evident as SRR increased 55 times relative to the control sediment. At the same time MPR of a similar order of magnitude to the SRR were observed in the amended sediment, although sulfate was present in high concentrations ( 5 to $60 \mathrm{mM}$ ). Potential substrates for both processes were highly available, e.g. acetate concentrations attained a maximum value of $\sim 5 \mathrm{mM}$ after $\sim 300 \mathrm{~h}$ of incubation. SRR apparently controlled the acetate turnover, since no acetate oxidation was found in the molybdate-inhibited incubations. This also indicates that $\mathrm{CH}_{4}$ production from acetate did not occur, and the absence of ${ }^{14} \mathrm{CO}_{2}$ production with molybdate inhibition showed that acetate-consuming respiratory processes other than sulfate reduction were absent. The acetate oxidation rates were equal to the SRR expressed in carbon equivalents until $\sim 180 \mathrm{~h}$ of incubation, but the subsequent decreasing role of acetate suggested that SRB utilize other substrates. Accumulation of fermentation products dur- 
ing molybdate inhibition is often used to examine possible substrates for SRB (Sørensen et al. 1981, Parkes et al. 1989), although increasing hydrogen pressure due to the inhibition of sulfate reduction may influence hydrogen-sensitive fermentation processes. This may result in lowered fatty acid oxidation or a shift to other fermentation pathways leading to accumulation of atypical products (Monetti \& Scranton 1992). In molybdate-treated sediment both acetate and propionate accumulated over the long term in contrast to only acetate in the noninhibited sediment. The accumulations suggest, in accordance with findings in other marine sediments (Sørensen et al. 1981, Parkes et al. 1989, 1993), that propionate is a substrate for SRB. It may, however, be an indication of incomplete oxidation reactions due to suppression of hydrogen-sensitive fermentation reactions. The formation of $\mathrm{H}_{2}$ and acetate from propionate is thermodynamically more sensitive to $\mathrm{H}_{2}$ inhibition than similar reactions involving e.g. butyrate and ethanol (McInerney 1988, Monetti \& Scranton 1992). No other SCFA accumulated in the present incubations, suggesting acetate as the predominant substrate for SRB. Acetate is the major SCFA product from the decomposition of food pellets (Hansen et al. 1993, Holmer \& Kristensen in press). The SRB present in the amended sediment was probably an acetate-selected population. Accordingly, in mixed cultures of SRB the addition of specific substrates has resulted in enhanced growth of the corresponding SRB population (Parkes et al. 1993).

The similarity between acetate oxidation and sulfate reduction initially, and between oxidation rates and depletion of the acetate pool towards the end in the noninhibited sediment, indicates that the acetate pool was entirely bioavailable. In the molybdate-inhibited treatment the initial accumulation rates of acetate and propionate were lower compared to the acetate accumulation and oxidation in the noninhibited sediment (in carbon equivalents). A similar relationship has been observed in other coastal sediments, and these studies suggest that only a part of the acetate present exists in a bioavailable pool, leading to an overestimation of the oxidation rates (Christensen 1984. Shaw et al. 1984, Novelli et al. 1988, Gibson et al. 1989). This is based on the fact that SRR are usually lower than acetate oxidation rates, but SRR may have been underestimated, as only acid volatile sulfides were extracted from the sediments during the radiotracer SRR assay (Christensen 1984, Shaw et al. 1984, Gibson et al. 1989). The fermentation processes may, as commented above, be affected by the inhibition of sulfate reduction, leading to an underestimation of the accumulation rates in the examined sediments as well as in this study

\section{Acetate oxidation in control sediments}

In control sediments the acetate oxidation attained rates similar to those of the sulfate reduction, and no measurable acetate oxidation was evident during molybdate inhibition, suggesting acetate as the sole substrate for SRB. Methane production was not present. During long-term molybdate inhibition, both acetate and propionate accumulated, propionate however only towards the end. Acetate accumulation attained a rate of only 1 to $20 \%$ of the SRR measured in the noninhibited sediment, which corresponds to the pattern observed in the amended sediment. The correspondence between acetate oxidation rates and SRR indicate as found for the amended sediment that all acetate measured in this sediment was bioavailable. The present rate constants and pools of acetate were relatively low compared to other sediments (Christensen \& Blackburn 1982, Christensen 1984, Shaw et al. 1984, Novelli et al. 1988, Gibson et al. 1989).

\section{Coexistence of SRB and MPB}

The stoichiometric relationship between $\mathrm{TCO}_{2}$ accumulation and $\mathrm{SO}_{4}{ }^{2-}$ consumption was low during the entire experiment $\left(\Delta \mathrm{TCO}_{2} / \Delta \mathrm{SO}_{4}{ }^{2-}\right.$ ratio of $0.8 ; \mathrm{R}^{2}=$ 0.94 ) compared to the ratio of 2 during acetate oxidation (Table 1, reaction 1 ). The ratio obtained may even be overestimated due to $\mathrm{TCO}_{2}$ production from fermentation processes as indicated by the $\mathrm{TCO}_{2}$ accumulation found in the inhibited sediment. Nevertheless, the low ratio demonstrates a $\mathrm{CO}_{2}$ deficit, which suggests 3 possible routes for the terminal mineralization processes: (1) sulfate is reduced without concomitant $\mathrm{CO}_{2}$ production; (2) propionate is the most important substrate for the SRB, and a ratio of 1.7 is obtained between $\mathrm{CO}_{2}$ and $\mathrm{SO}_{4}{ }^{2-}$ (Table 1, reaction 2); (3) utilization of $\mathrm{CO}_{2}$ by $\mathrm{MPB}$ during the reduction with $\mathrm{H}_{2}$ to $\mathrm{CH}_{4}$ (Table 1, reaction 5). The fact that SRR are higher than the acetate oxidation rates suggests the presence of other favourable substrates for SRB, i.e. propionate and $\mathrm{H}_{2}$. The use of propionate will, however, only cause a minor reduction in the accumulation of $\mathrm{CO}_{2}$. Stimulation of SRB by high hydrogen pressure has been found in sediment slurries (Monetti \& Scranton 1992). This mechanism may support the first route for the $\mathrm{CO}_{2}$ deficit. Since acetate was not an important substrate for the MPB, the third route also has to be considered. Studies of marine sediments have shown that MPB primarily use $\mathrm{CO}_{2}$ and $\mathrm{H}_{2}$ as substrates (Sørensen et al. 1981, Crill \& Martens 1986, Blair \& Carter 1992). In natural sediments the competition between SRB and MPB may be strongly related to the $\mathrm{H}_{2}$ pressure (Abram \& Nedwell 1978, Kristjansson et al. 
Table 1. Pathways for the oxidation of important electron donors during sulfate reduction and methanogenesis

Sulfate reduction (from Widdel 1988)
(1) Acetate:
$\mathrm{CH}_{3} \mathrm{COO}^{-}+\mathrm{SO}_{4}{ }^{2-} \longrightarrow 2 \mathrm{HCO}_{3}^{-}+\mathrm{HS}^{-}$
(2) Propionate:
$4 \mathrm{CH}_{3} \mathrm{CH}_{2} \mathrm{COO}^{-}+3 \mathrm{SO}_{4}{ }^{2-} \longrightarrow 4 \mathrm{CH}_{3} \mathrm{COO}^{-}+4 \mathrm{HCO}_{3}^{-}+3 \mathrm{HS}^{-}+\mathrm{H}^{+}$
(3) Hydrogen:
$4 \mathrm{H}_{2}+\mathrm{SO}_{4}{ }^{2-}+\mathrm{H}^{+} \longrightarrow 4 \mathrm{H}_{2} \mathrm{O}+\mathrm{HS}^{-}$

$$
\begin{aligned}
& \Delta G_{0}=-47.6 \mathrm{~kJ} \mathrm{~mol}^{-1} \\
& \Delta G_{0}=-150.6 \mathrm{~kJ} \mathrm{~mol}^{-1} \\
& \Delta G_{0}=-152.2 \mathrm{~kJ} \mathrm{~mol}^{-1}
\end{aligned}
$$

Methanogenesis (from Brock \& Madigan 1991)
(4) Acetate
$4 \mathrm{CH}_{3} \mathrm{COO}^{-} \longrightarrow 3 \mathrm{CH}_{4}+\mathrm{HCO}_{3}^{-}$
(5) Hydrogen:
$4 \mathrm{H}_{2}+\mathrm{CO}_{2} \rightarrow \mathrm{CH}_{4}+\mathrm{H}_{2} \mathrm{O}$

$\Delta G_{0}=-31.0 \mathrm{~kJ} \mathrm{~mol}^{-1}$
$\Delta G_{0}=-134.0 \mathrm{~kJ} \mathrm{~mol}^{-1}$
1982, Sansone \& Martens 1982), where the SRB consumes hydrogen due to the higher affinity, and thereby suppresses the MPB. At high hydrogen pressures, however, SRB and MPB may coexist and attain equal rates of $\mathrm{H}_{2}$ consumption (Kristjansson et al. 1982). In the present experiment the rapidly increasing methane production rates during the initial period and the high and constant rates later indicate that a persistent source of substrate was available for the MPB. $\mathrm{CO}_{2}$ and $\mathrm{H}_{2}$ are the 2 most likely substrates, as $\mathrm{CO}_{2}$ was present in high concentrations and there was a large potential for $\mathrm{H}_{2}$ production from fermentation of e.g. fatty acids in this metabolically active sediment (Monetti \& Scranton 1992). A stoichiometric calculation based on the ratio of 2 during acetate oxidation estimates the loss of $\mathrm{CO}_{2}$ as $\sim 1700 \mathrm{nmol} \mathrm{cm} \mathrm{cm}^{-3} \mathrm{~d}^{-1}$. This rate is of a similar order of magnitude as the average methane production rates $\left(\sim 1000 \mathrm{nmol} \mathrm{cm} \mathrm{cm}^{-3} \mathrm{~d}^{-1}\right)$, but may also support the use of $\mathrm{H}_{2}$ by SRB.

The rapidly decreasing $S R R$ towards the end were possibly due to the depletion of acetate or other substrate pools. The decreasing SRR may, however, also be due to an inhibition of the SRB by e.g. dissolved sulfides which accumulated to high levels (>20 mM). Sulfide inhibition of SRB has been found in pure cultures (Reis et al. 1992) and has been suggested as the cause for low SRR in a comparable study with an amended sediment similar to the one used here (Holmer \& Kristensen in press).

The present study has shown that SRB and MPB may coexist at high sulfate concentrations in sediments supplied with labile organic matter. Evidence for coexistence between SRB and MPB has been observed in situ at the farming site, as methane accumulated in the sulfate rich surface layers of the sediments (Holmer \& Kristensen unpubl.). The organic matter added in this experiment corresponded to a $12 \%$ increase in the total pool, but up to 12 times higher levels of organic matter have been found at the fish farming site (Holmer \& Kristensen 1992). When present, SCFA were used as substrates by SRB with acetate as the most important. There was only limited competition between SRB and MPB for acetate, as the inhibition of SRB only had minor effect on MPR. The results indicate that $\mathrm{CO}_{2}$ and $\mathrm{H}_{2}$ may be major substrates for MPB. Based on the mineralized products $\left(\mathrm{TCO}_{2}\right.$ accumulation and $\mathrm{CO}_{2}$ used for methane production) a rapid decomposition of food pellets was encountered with a half-life of the added organic matter of $\sim 50 \mathrm{~d}$ at $5^{\circ} \mathrm{C}$.

Acknowledgement. M.H. was supported by a grant from Odense University

\section{LITERATURE CITED}

Abram, J. W., Nedwell, D. B. (1978). Hydrogen as a substrate for methanogenesis and sulphate reduction in anaerobic saltmarsh sediment. Arch. Microbiol. 117: 93-97

Blair, N. E., Carter, W. D. (1992). The carbon isotope biogeochemistry of acetate from a methanogenic marine sediment. Geochim. Cosmochim. Acta 56: 1247-1258

Brock, T. D., Madigan, M. T (1991). Biology of microorganisms, 6th edn. Prentice-Hall International, Inc., Englewood Cliffs, NJ

Bøtte, H. F., Jørgensen, L. (1992). Evaluation of low-conductance eluents for suppressed ion-exclusion chromatography. J. Chromatogr. 602: 27-31

Christensen, D. (1984). Determination of substrates oxidized by sulfate reduction in intact cores of marine sediments. Limnol. Oceanogr. 29(1): 189-192

Christensen, D., Blackburn, T H. (1982). Turnover of ${ }^{14} \mathrm{C}$ labelled acetate in marine sediments. Mar. Biol, 71: $113-119$

Crill, P. M., Martens, C. S. (1986). Methane production from bicarbonate and acetate in an anoxic marine sediment. Geochim. Cosmochim. Acta 50: 2089-2097

Fossing, H., Jørgensen, B. B. (1989). Measurement of bacterial sulfate reduction in sediments: evaluation of a singlestep chromium reduction method. Biogeochemistry 8: 205-222

Gibson, G. R., Parkes, R. J., Herbert, R. A. (1989). Biological availability and turnover rate of acetate in marine and estuarine sediments in relation to dissimilatory sulphate reduction. FEMS Microbiol. Ecol. 62: 303-306

Hall, P. O. J., Aller, R. C. (1992). Rapid, small-volume, flow injection analysis for $\mathrm{CO}_{2}$ and $\mathrm{NH}_{4}+$ in marine and freshwaters. Limnol. Oceanogr. 37(5): 1113-1118

Hall, P. O. J., Anderson, L. G., Holby, O., Kollberg, S., Samuelsson, M. O. (1990). Chemical fluxes and mass balances in a marine fish cage farm. I. Carbon. Mar. Ecol. Prog. Ser. 61:61-73 
Hansen, L. S., Holmer, M., Blackburn, T H. (1993). Mineralization of organic nitrogen and carbon (fish food) added to anoxic sediment microcosms: role of sulphate reduction. Mar. Ecol. Prog. Ser. 102: 199-204

Holmer, M., Kristensen, E. (1992). Impact of marine fish cage farming on metabolism and sulfate reduction of underlying sediments. Mar. Ecol. Prog. Ser. 80: 191-201

Holmer, M., Kristensen, E. (in press). Organic matter mineralization in an organic-rich sediment: experimental stimulation of sulfate reduction by fish food pellets. FEMS Microbiol. Ecol.

Kristensen, E., Andersen. F. Ø. (1987). Determination of organic carbon in marine sediments: a comparison of two CHN-analyzer methods. J. exp. mar. Biol. Ecol. 109: 15-23

Kristjansson, J. K., Schönheit, P., Thauer, R. K. (1982). Different $K_{\mathrm{s}}$ values for hydrogen of methanogenic bacteria and sulfate reducing bacteria: an explanation for the apparent inhibition of methanogenesis by sulfate. Arch. Microbiol. 131. 278-282

Kruse, B. (1993). Measurement of plankton $\mathrm{O}_{2}$ respiration in gas-tight plastic bags. Mar. Ecol. Prog. Ser. 94: 155-163

Kuivila, K. M., Murray, J. W., Devol, A. H. (1990). Methane production in the sulfate-depleted sediments of two marine basins. Geochim. Cosmochim. Acta 54: 403-411

Lund, B., Blackburn, T. H. (1989). Urea turnover in a coastal marine sediment measured by a $\left[{ }^{14} \mathrm{C}\right]$ urea short-term incubation. J. microbiol. Meth. 9: 297-308

Niartens, C. S., Klump, J. V. (1984). Biogeochemical cycling in an organic-rich coastal marine basin 4 . An organic car bon budget for sediments dominated by sulfate reduction and methanogenesis. Geochim. Cosmochim. Acta 48: $1987-2004$

Mclnerney, M. J. (1988). Anaerobic hydrolysis and fermentation of fats and proteins. In: Zehnder, A. J. B. (ed.) Biology of anaerobic microorganisms. John Wiley \& Sons, New York

Monetti, M. A., Scranton, M. I. (1992). Fatty acid oxidation in anoxic marine sediments: the importance of hydrogen sensitive reactions. Biogeochemistry 17: 23-47

Novelli, P. C., Michelson, A. R., Scranton, M. I., Banta, G. T. Hobbie, J. E., Howarth, R. W. (1988). Hydrogen and acetate cycling in two sulfate-reducing sediments: Buzzards Bay and Town Cove, Mass. Geochim. Cosmochim Acta 52: 2477-2486

This article was submitted to the editor
Oremland, R. S., Capone, D. G. (1988). Use of 'specific' inhibitors in biogeochemistry and microbial ecology. In: Marshall, K. C. (ed.) Advances of microbial ecology, Vol. 10. Plenum Publishing Corporation, London, p. $285-383$

Oremland, R. S., Taylor, B. F. (1978). Sulfate reduction and methanogenesis in marine sediments. Geochim. Cosmochim. Acta 42: 209-214

Parkes, R. J., Dowling, N. J. E., White, D. C., Herbert, R. A., Gibson, G. R. (1993). Characterization of sulphate-reducing bacterial populations within marine and estuarine sediments with different rates of sulfate reduction. FEMS Microbiol. Ecol. 102: 235-250

Parkes, R. J., Gibson, G. R., Mueller-Harvey, I., Buckingham, W. J., Herbert, R. A. (1989). Determination of the substrates for sulphate-reducing bacteria within marine and estuarine sediments with different rates of sulphate reduction. J. gen. Microbiol. 135: 175-187

Reeburgh, W. S. (1968). An improved interstitial water sampler. Limnol. Oceanogr. 163-165

Reis, M. A. M., Almeida, J. S., Lemos, P. C., Carrondo, M. J. T. (1992). Effect of hydrogen sulfide on growth of sulfate reducing bacteria. Biotechnol. Bioeng. 40:593-600

Sansone, F. J., Martens, C. S. (1981). Determination of volatile fatty acid turnover rates in organic-rich marine sediments. Mar. Chem. 10: 233-247

Sansone, F. J., Martens, C. S. (1982). Volatile fatty acid cycling in organic-rich marine sediments. Genchim Cosmochim. Acta 46: 1575-1589

Schönheit, P., Kristjansson, J. K., Thauer, R. K. (1982). Kinetic mechanism for the ability of sulfate reducers to outcompete methanogens for acetate. Arch. Microbiol. 132: 285-288

Shaw, D. G., Alperin, M. J., Reeburgh, W. S., McIntosh, D. J. (1984). Biogeochemistry of acetate in anoxic sediments of Skan Bay, Alaska. Geochim. Cosmochim. Acta 48: $1819-1825$

Sørensen, J., Christensen, D., Jørgensen, B. B. (1981). Volatile fatty acids and hydrogen substrates for sulfate-reducing bacteria in anaerobic marine sediments. Appl. environ. Microbiol. 42: 5-11

Widdel, F. (1988). Microbiology and ecology of sulfate- and sulfur-reducing bacteria. In: Zehnder, A. J. B. (ed.) Biology of anaerobic microorganisms. John Wiley \& Sons, New York

Manuscript first received: Novernber 26, 1993

Revised version accepted: February 24, 1994 